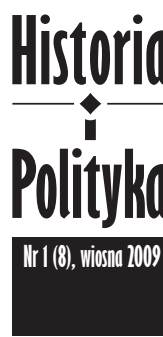

\section{Maciej Cesarz, Od „Większej Brytanii” do zjednoczonej Europy. Faszystowska doktryna Oswalda Mosleya, Wrocław 2006, ss. 389}

0 swald Mosley (1896-1980), był postacią kontrowersyjną i barwną ${ }^{1}$, zasłynął przede wszystkim jako założyciel w roku 1932 Brytyjskiej Unii Faszystów (British Union of Fascists BUF $)^{2}$, przemianowanej w roku 1936 na Brytyjską Unię Faszystów i Narodowych Socjalistów. Natomiast już po wojnie, w roku 1948, był twórcą Ruchu Zjednoczenia (Union Movement - UM).

Mosley na początku swej aktywności politycznej związany był z Partią Konserwatywną, z ramienia, której $\mathrm{w}$ wieku 22 lat zostaje deputowanym do Izby Gmin, w wyborach z roku 1922 dostał się do tejże Izby jako kandydat nie-

${ }^{1} \mathrm{~W}$ życiu osobistym znany był z licznych romansów (m.in. z siostrą swojej drugiej żony i jej matką), w roku 1920 poślubił córkę znanego polityka, wicekróla Indii Georga Curzona. Na ślubie był obecny król Jerzy V. Po śmierci pierwszej żony, Mosley w 1936 r. pobrał się z Dianą Mitford, ślub odbył się w Niemczech w domu Josepha Goebbelsa, w czasie uroczystości obecny był Adolf Hitler.

${ }^{2}$ Zob. http://www.oswaldmosley.com/british-union.htm (przeglądane 14 I 2009 r.). zależny, zaś w roku 1924 r. wstąpił do Partii Pracy. W 1929 r. został ministrem bez teki w laburzystowskim rządzie, gdzie zajmował się przede wszystkim sprawami związanymi z bezrobociem. W marcu 1931 r. zniechęcony polityką laburzystów, a szczególnie niemożnością realizacji własnego programu przeciwdziałania bezrobociu, stworzył własne ugrupowanie pod nazwą Nowa Partia. Ugrupowanie to miało już znamiona partii protofaszystowskiej. Dopiero jednak po przegranych wyborach $w$ roku 1931, Mosley zaczyna coraz bardziej poszukiwać nowych rozwiązań, w styczniu 1932 r. spotkał się z Benito Mussolinim, zaczął wyraźnie odwoływać się do włoskich wzorców, szczególnie jeśli chodziło o organizację wewnętrzną BUF, która szybko zasłynęła z radykalnych haseł, a jej paramilitarne bojówki „blackshirts”, dały się poznać ze stosowania przemocy wobec komunistów i mniejszości żydowskiej. Głośnym echem odbił się zorganizowany 7 czerwca 1934 r. wiec BUF w londyńskiej Olympia Hall. Było to największe zgromadzenie zwolenników Mosleya, a jednocześnie olbrzymia manifestacja antyfaszystowska Partii Komunistycznej (Communist Party), w czasie próby zagłuszenia wiecu przez komunistów doszło do wielu aktów przemocy. Na skutek akcji BUF, a także manifestacji grup lewicowych, rząd wprowadził z dniem 1 stycznia 1937 r. akt mający na celu utrzymać porządek publiczny (Public Order Act), zgodnie z nim zakazano nosić działaczom partii politycznych uniformów przypominających wojskowe, poszerzono także uprawnienia policyjne wobec demonstrantów ${ }^{3}$. Największy rozwój partii Mosleya przypadał na

\footnotetext{
${ }^{3}$ http://www.oswaldmosley.com/britishunion.htm (przeglądane 14 I 2009 r.).
} 
lata 1934/1935 wówczas ugrupowanie osiągnęło liczbę zwolenników szacowaną na 40-50 tys., co było dużym sukcesem, szczególnie w kraju o stabilnym systemie politycznym. Zbliżająca się wojna spowodowała jednak, iż zainteresowanie ruchem faszystowskim w Wielkiej Brytanii spadło. Od roku 1936 BUF zaczął głosić hasła antywojenne. Kampania odbywała się pod hasłem „Mosley for Peace", a działacze BUF zaczęli przedstawiać wojnę jako wyraz „żydowskich i komunistycznych aspiracji" 4 .

Po wybuchu wojny Mosley początkowo wraz z kilkudziesięcioma działaczami BUF został internowany, następnie zaś na mocy dekretu 18B, w roku 1940 aresztowany, nigdy formalnie nie postawiono przywódcy BUF żadnych zarzutów. Ze względu na zły stan zdrowia został zwolniony w 1943 r. Po wojnie, jak już wspomniano, Mosley założył Ruch Zjednoczenia. Ruch nie osiągnął nigdy tak wielu zwolenników jak BUF. W 1973 r. Ruch Zjednoczenia przestał istnieć, przekształcając się w Partię Czynu (Action Party). Jeśli chodzi o program UM głosił pewne wątki zaczerpnięte z lat trzydziestych, poruszał także nowe tematy, wszystkie prezentowane były w nowym europejskim kontekście. Po zakończeniu wojny Mosley miał oświadczyć: „faszyzm umarł. Teraz musimy stworzyć Europę”5.

${ }^{4}$ M. Cesarz, Od „Większej Brytanii" do zjednoczonej Europy. Faszystowska doktryna Oswalda Mosleya, Wrocław 2006, s. 92.

5 Cyt. za: M. Cesarz, op. cit., s. 108.
Myślą polityczną Oswalda Mosleya zajął się Maciej Cesarz, który opublikował na ten temat kilka artykułów ${ }^{6}$.Zwieńczeniem badań stała się napisana na podstawie dysertacji doktorskiej książka: „Od «Większej Brytanii» do zjednoczonej Europy. Faszystowska doktryna Oswalda Mosleya".

Omawiana książka posiada układ problemowy. Składa się z czterech rozdziałów i dość dużej liczby podrozdziałów, dzięki którym czytelnik łatwiej porusza się w opisywanie materii. W rozdziale pierwszym autor omówił genezę faszyzmu brytyjskiego, przedstawił sytuację polityczną i zachodzące zmiany wewnątrz Imperium Brytyjskiego, za czasów panowania Edwarda VII (1901-1910). Wówczas okazało się, że dotychczasowe mniemanie o niezwyciężoności militarnej Imperium zostało nadszarpnięte w czasie wojny burskiej, zaostrzał się wówczas także konflikt irlandzki. Epoka edwardiańska, to także kształtowanie się społeczeństwa masowego oraz czas przeprowadzenia przez rząd reform społecznych. Polityczny i społeczny klimat przełomu epok stworzył korzystne warunki, do wzrostu aktywności ugrupowań rady-

${ }^{6}$ Faszyzm paneuropejski czy alternatywna wizja integracji? Koncepcja Zjednoczonej Europy Oswlada Mosleya, Politeja, 2006, nr 2; Z badań nad problematyka własności $w$ ideologii faszystowskiej Oswalda Mosleya, Acta Universitatis Wratislaviensis. Studia nad Faszyzmem i Zbrodniami Hitlerowskimi, T. 27 (2004); Wybrane zagadnienia społeczne faszystowskiej myśli Oswalda Mosleya, Acta Universitatis Wratislaviensis. Przegląd Prawa i Administracji, T. 60 (2004). 
kalnych i antyliberalnych. Odwołujące się do tradycji Brytanii imperialnej. Język ówczesnej prawicy a także środki propagandy nacjonalistycznej stały się inspiracją dla Mosleya. Maciej Cesarz wskazuje, w omawianym rozdziale, iż nie bez znaczenia było także występujące po zakończeniu I wojny światowej rozczarowanie epoką oraz przemiany, jakie zachodziły wewnątrz Imperium Brytyjskiego, przekształconego w Brytyjską Wspólnotę Narodów. Cesarz przedstawia $\mathrm{w}$ tym rozdziale także idee, które miały wpływ na poglądy Oswalda Mosleya. Chodzi tu przede wszystkim o darwinizm społeczny, socjalny-imperializm (chcący zdobyć dla idei imperialnej środowiska robotnicze), a także antyracjonalizm i antypozytywizm, takich myślicieli jak Fryderyk Nietzsche, Henri Bergson, Georges Sorel i Gustav Le Bon. U genezy brytyjskiego faszyzmu leżały oczywiście także wzorce płynące z Italii, których recepcja była dość łatwa w środowiskach zniechęconych nie tylko polityką liberalną, ale także demokracją parlamentarną. Istniała także pewna ilość organizacji, które istniały przed powstaniem BUF, a były ugrupowaniami protofaszystowskimi. Grupy te były wskazywane przez samego Mosleya, jako protoplasci brytyjskiego faszyzmu, ponieważ $\mathrm{w}$ ten sposób lider BUF starał się legitymizować faszyzm brytyjski, twierdząc, że był on wytworem rodzimej tradycji. Organizacje te miały zazwyczaj charakter militarystyczny, kombatancki i imperialny, głosiły zaś hasła antykomunistyczne i antysemickie (Ochotnicy Ulsterscy, Liga Braci Brytyjskich, Brytyjscy Faszyści). Inspiracją były także, podobnie zresztą jak w innych faszyzmach, najczęściej idealizowane tradycje historyczne (w wypadku Mosleya era elżbietańska), ale tak- że idee mówiące o potrzebie stworzenia nowego człowieka.

Generalnie rzecz ujmując na faszystowską myśl twórcy BUF wpłynęły różnorodne tradycje polityczne oraz przekonanie, że nadchodzi nowa era, która przyniesie nowy typ człowieka, uzbrojonego $\mathrm{w}$ nowe idee. $\mathrm{W}$ brytyjskim faszyzmie dochodziły do głosu dwie dychotomiczne tradycje - modernizacyjna i antymodernizacyjna ${ }^{7}$.

W rozdziale pierwszym przedstawione są także ugrupowania utworzone przez Mosleya, a więc protofaszystowska Nowa Partia oraz Brytyjska Unia Faszystów i Ruch Zjednoczenia.

Rozdział drugi dotyczy filozofii faszyzmu Oswalda Mosleya. Autor pokazał w nim wyraźne fascynacje twórcy BUF historiozofią Oswalda Spenglera, który w książce „Zmierz Zachodu” przewidywał upadek cywilizacji Zachodu. Mosley przyjmował większość tez niemieckiego uczonego, podobnie jak on krytykował cywilizację zachodnioeuropejską postrzegając ją jako sztuczny zurbanizowany i chylący się ku upadkowi twór. Nie zgadzał się jednak z pesymistycznymi twierdzeniami Spenglera, gdyż uważał, iż faszyzm przyczyni się do odwrócenia biegu historii, doprowadzając do faszystowskiej odnowy kultury. Odrodzenie narodowe było ideą „Większej Brytanii", którą Mosley sformułował w książce o tym samym tytule - „The Greater Britain". Na poglądach Spenglera zrodził się także mosleyowska idea kolektywistycznego cezaryzmu. Niemiecki historiozof twierdził bowiem, iż nastąpi zanik elit, a decydującą rolę odgrywać będą masy z cezarem na czele. Mosley głosił zaś pogląd, iż cezaryzm przełamie dyktat pie-

\footnotetext{
${ }^{7}$ M. Cesarz, op. cit., s. 20-21.
} 
niądza i zniszczy jego polityczną broń w postaci demokracji. Wśród intelektualistów stanowiących wzór dla przywódcy BUF ważne miejsce zajmował także Wilhelm Fridrich Hegel. Dzięki recepcji dialektyki Hegla, myśl przywódcy brytyjskich faszystów stała się spójna, łączyła atawizm z dążeniem do modernizacji jak i odwołanie do postulatów zarówno prawicy jak i lewicy. Mosley, podobnie jak Hegel, jako zasadniczą wartość poznawczą uznawał doświadczenie, był także zwolennikiem cykli kulturowych. Maciej Cesarz w rozdziale drugim omawia również ideę rewolucji dynamicznej głoszonej przez Mosleya, wynikającą z przekonania przywódcy BUF, iż idee powinny głęboko poruszać emocje człowieka - była to więc idea czynu. Miała ona głębokie konotacje z faszystowską dynamiczną koncepcją życia. „Był to dynamizm rewolucyjny, modernistyczny; skierowany przeciw zastanej rzeczywistości; przepojony aktywizmem i ukrytym kultem walki [...]"8.

Rozdział trzeci: „Ideologia polityczna i społeczna Oswalda Mosleya do roku 1940", omawia ideologię Brytyjskiej Unii Faszystów, szczególnie zaś nacjonalizm Mosleya, który nadawał narodowi brytyjskiemu pewnych cech, dystynktywnych wyłącznie dla brytyjskiej tożsamości. „Nacjonalizm BUF, inspirowany ideami Oswalda Mosleya, w istocie propagował typ postawy społeczno-politycznej, która za najważniejszy uznaje interes narodu brytyjskiego, podporządkowując mu całość działań politycznych oraz uznając za najlepszy model organizacji społecznej, złączonej wspólnym pochodzeniem, językiem, kulturą i historią"9. Nacjonalizm ten nie miał jednak cech rasistowskich.

\footnotetext{
8 Ibidem, s. 168.
}

9 Ibidem, s. 183.
Był to nacjonalizm holistyczny, w nim to wspólnota narodowa stanowiła podstawę opisu jednostki. Holistyczna teoria narodu prezentowana przez Mosleya zakładała, że rodzina, państwo i instytucje mogą posiadać jedną wolę. $W$ rozdziale tym zaprezentowane są faszystowskie koncepcje gospodarcze Mosleya. Była to swoista trzecia droga pomiędzy kolektywizmem a kapitalizmem, głosząca hasła solidarystyczne, autarkiczne i etatystyczne. Można zadać pytanie, czy program ten walczył z własnością prywatną? Teoretycznie nie, gdyż działacze BUF zakładali jej respektowanie, z drugiej strony jednak podkreślali służebną rolę własności w stosunku do interesu narodowego, co mogło prowadzić do ograniczenia prawa własności. W myśl koncepcji Mosleya, faszyzm miał kontrolować gospodarkę nie zaś własność prywatną.

Podstawą jednak koncepcji Mosleya była chęć budowy państwa korporacyjnego. Takie państwo przywódca BUF uważał za bliskie tradycji brytyjskiej (średniowieczne gildie), dążył wiec do przebudowy ustroju gospodarczego, społecznego i politycznego $\mathrm{w}$ wertykalne struktury (zrzeszających pracodawców, pracobiorców i wszystkie inne osoby wykonujące tę samą profesję). Jak zauważył autor omawianej książki, nominalnie korporacjonizmowi przydawano cech samorządności jednak faktycznie miały one ograniczone uprawnienia, gdyż funkcjonowały pod kontrolą rządu i Narodowej Korporacji.

Rozdział trzeci zawiera także opis programu polityki zagranicznej, w której najistotniejszą cechą była koncepcja powołania korporacyjnych imperiów, które stwarzałby poszczególnym nacjom możliwości rozwoju. Maciej Cesarz w oddzielnym podrozdziale omawia także 
„Program selektywnego pacyfizmu”, który przejawiał się m.in. popieraniem polityki appeasmentu.

Rozdział ostatni omawia próby rehabilitacji Mosleya na tle odrodzenia faszyzmu po II wojnie światowej w Wielkiej Brytanii. Później zaś prezentuje zachodzącą pewną transformację poglądów Mosleya. Najistotniejszy jest jednak podrozdział „Faszyzm paneuropejski od Imperium Brytyjskiego do zjednoczonej Europy". Mosley po wojnie porzucił koncepcje dotyczące rozwoju Imperium Brytyjskiego, gdyż uznał za ważniejsze stworzenie trzeciego równorzędnego bloku w stosunku do istniejącego dwubiegunowego świata. Przeciwwagę dla istniejących mocarstw stanowić miała zjednoczona, silna i spójna Europa. Mosley głosił przebudowę starego kontynentu i stworzenie zunifikowanego „Narodu Europejskiego”. Był, co może trochę dziwić, zwolennikiem pełnej integracji, gdyż, według niego, tylko daleko posunięta unifikacja mogła zniwelować wewnętrzne sprzeczności między narodami europejskimi. Można więc śmiało określić przywódcę UM - jako skrajnego paneuropejskiego federalistę. Rodzi się pytanie czy Mosley nie obawiał się utraty świadomości narodowej przez poszczególne nacje europejskie, otóż zakładał on, że podobnie jak w przypadku Wielkiej Brytanii, na kontynencie może zaistnieć podwójna świadomość, z jednej strony narodowa (jak Szkotów, Walijczyków, Anglików w Wielkiej Brytanii) z drugiej zaś ogólniejsza europejska (analogicznie jak świadomość narodowa Brytyjczyków realizowana przez ideę Zjednoczonego Królestwa).

W powojennych poglądach Mosleya wyraźnie widać lęk przed utratą „europejskiej tożsamości”. Z tych względów opowiadał się za wprowadzeniem kontroli imigracji, ograniczeniem małżeństw mieszanych, tłumacząc to prawem do zachowana własnej rasy i kultury. Przemawiał więc przez niego, eurocentryzm, zaś projektowane przez niego trzy bloki polityczne byłyby oparte na odseparowanych strukturach różniących się od siebie zarówno cywilizacyjnie, gospodarczo jak i politycznie.

W powojennej doktrynie Mosleya wyraźnie widać antyegalitaryzm, antyliberalizm, antykomunizm, autorytaryzm, elitaryzm, rasizm i nacjonalizm. Rodzi się pytanie czy poglądy brytyjskiego faszysty uległy głębokiej przemianie między okresem przedwojennym a powojennym, zdaje się słusznie zauważa Cesarz, iż: „[...] postulat gruntownej integracji europejskiej zastąpił kultywowany niegdyś mit brytyjskiego odrodzenia. Nastąpiła tu raczej transpozycja pewnego ideału niż transformacja ideologicznych założeń" ${ }^{10}$.

Napisana przez Macieja Cesarza książka w sposób interesujący przedstawia poglądy twórcy specyficznego wyspiarskiego faszyzmu, który jest prawie nieznany w Polsce. Sama zaś faszystowska myśl Mosleya nie była tylko przeniesieniem Włoskich czy Niemieckich wzorców, ale stanowiła znacznie szerszą syntezę wpływów ideowych, przy czym sam Oswald Mosley był nie tylko politykiem, ale także teoretykiem brytyjskiego faszyzmu. Szczególnie zaś interesująco jawią się jego powojenne poglądy mówiące o stworzeniu silnie zintegrowanej Europy.

Maciej Cesarz wykazał się dużą znajomością nie tylko myśli faszystowskiej, ale także innych nurtów ideowych, zaś

\footnotetext{
10 Ibidem, s. 364.
} 
sama myśl przywódcy BUF opisana została na szerokim tle.

W książce autorowi, ze względu na problemowy charakter pracy, nie udało się jednak ustrzec przed dość dużą ilością powtórzeń, co jest niewątpliwie minusem w strukturze pracy.

„Od «Większej Brytanii» do zjednoczonej Europy. Faszystowska doktryna
Oswalda Mosleya", jest jednak pracą bardzo cenną i powinna znaleźć się biblioteczne każdego badacza zarówno faszystowskiej jak i nacjonalistycznej myśli politycznej.

Patryk Tomaszewski (Toruń) 